\title{
MOVIMENTO INDÍGENA E OS INDÍGENAS EM MOVIMENTOS: MESMOS SONHOS, OUTROS CAMINHOS
}

The indigenous movement and indigenous people in movements:

the same dreams, other paths

ANTÔNIO CARDOSO DA SILVA ${ }^{1}$

UNIR

\section{RESENHA}

MUNDURUKU, Daniel ${ }^{2}$. O caráter educativo do movimento indígena brasileiro (1970- 1990). São Paulo: Paulinas, 2012.

A obra ora resenhada foi estruturada pelo autor em duas partes. A primeira parte, que recebeu o título "Colocando os pingos nos is", possui dois capítulos. O primeiro capítulo, "O processo civilizatório e o movimento indígena brasileiro", aborda as políticas indigenistas e a visão sobre os povos indígenas, o paradigma exterminacionista, o paradigma integracionista, a Fundação Nacional do Índio, a Constituição Federal do Brasil como um novo paradigma para a política indigenista nacional e, finalmente, a transfiguração étnica e o movimento indígena.

1 Tecnólogo em logística empresarial (2009). Pós-graduado em gestão de pessoas e psicologia organizacional (2013). Graduando em Ciências Sociais, pela Universidade Federal de Rondônia (2018); Lattes http://lattes.cnpq.br/0141402449414107. E-mail: cardoso1963cardoso@ gmail.com .

2 Daniel Munduruku é graduado em Filosofia e doutor em Educação pela Universidade de São Paulo (USP). Tem pós-doutorado em Literatura pela Universidade Federal de São Carlos (UFSCar). É autor de 40 livros voltados para crianças, jovens e educadores. Recebeu importantes prêmios no Brasil e no exterior. É Comendador da Ordem do Mérito Cultural da Presidência da República e membro efetivo da Academia de Letras de Lorena, cidade onde reside. Muitos de seus livros receberam o selo de Altamente Recomendável pela Fundação Nacional do Livro Infantil e Juvenil (FNLIJ). Atualmente, é pesquisador da CAPES. É, ainda, considerado o mais importante escritor indígena brasileiro. 
Já o segundo capítulo, "Posso ser quem você é sem deixar de ser o que sou", trata sobre a gênese do movimento indígena brasileiro; o cenário dos anos 1970, quando surgem as assembleias indígenas, os anos 1980, com a organização macro e a organização micro, e os anos 1990, com a mudança nas relações interétnicas, com o protagonismo indígena.

A segunda parte foi divida em três capítulos. O primeiro capítulo, "Somos aqueles por quem esperamos" apresenta duas seções: um prólogo e outra intitulada "Por que esses?". O segundo capítulo, "Militância e memória", foi subdividido em: prólogo; Influência religiosa e escolaridade; Movimento Indígena; Visão de futuro; Avaliando as parcerias; Caráter educativo do Movimento indígena; e, finalmente, Autoavaliação e Conclusão. O terceiro capítulo, "O caráter educativo do movimento indígena brasileiro", foi, por sua vez, subdividido em três tópicos: Considerações finais; Entidades de apoio aos índios; $O$ movimento indígena como movimento popular; Imagens que se desfazem: educando a sociedade brasileira e, por fim, Referências Bibliográficas. Esse foi modo como o autor estruturou sua obra.

O objetivo da obra é, segundo o autor, "falar do Movimento Indígena brasileiro e de seu caráter educativo" (MUNDURUKU, 2012, p. 11). Embora o autor proponha falar do caráter educativo e de suas dificuldades, ele faz uma revelação sobre as dificuldades enfrentadas com o intuito de conscientizar as etnias. No capítulo 1, as primeiras palavras são: "Prezados parentes indígenas, não tem sido muito fácil para nossos povos viverem uma vida digna em terras brasileiras desde a chegada dos europeus, no século XVI" (MUNDURUKU, 2012, p. 23).

Vários autores desde os cronistas viajantes e da literatura brasileira tentaram retratar as dificuldades a que foram submetidos os povos indígenas, por vezes idealizando aqueles seres de hábitos e culturas estranhos aos padrões eurocêntricos adotados e socialmente aceitos. Se, em determinado momento, alguns autores os romantizam, em outro, demonizam-nos, atribuindo-lhes termos desqualificativos, 
como sendo improdutivos ou ainda, como "empecilhos e riscos". Segundo Manuela Carneiro da Cunha, "a partir do início dos anos 1980, de empecilhos, os índios passaram a ser riscos à segurança nacional" (2013, p. 21). Esse discurso se revela como um contrassenso; a autora, ao tomar por empréstimo a fala de Farage (1991), afirma: "é irônico que índios de Roraima, que haviam sido no século XVIII usados como muralha dos sertões garantindo as fronteiras brasileiras, fossem agora vistos como ameaças a essas mesmas fronteiras" (CARNEIRO DA CUNHA, 2013, p. 22).

Enquanto aceitaram ser submissos e dóceis à política colonialista, os indígenas foram considerados "muralhas dos sertões"; como agora lutam pelo seu reconhecimento, são vistos como "riscos à segurança nacional". É compreensível que Daniel Munduruku peça compreensão ao que ele denomina como "evento e fatores". "É importante que se entenda que cada evento é ocasionado por uma série de fatores que às vezes interagem entre si" (MUNDURUKU, 2012, p. 43).

Nesse processo de interação, Munduruku (2012) enfatiza a importância do que ele qualifica como sendo "visível". "Não é preciso assumir uma identidade, mas torná-la visível dentro do contexto social brasileiro" (MUNDURUKU, 2012, p. 48). Quando o autor questiona uma ausência de identidade, ele se posiciona de modo a ser ouvido pela sociedade nacional, porque, quando diz "não é preciso assumir uma identidade", fica explícito que não deseja que a sociedade brasileira dos "homens brancos" assuma sua identidade, mas que apenas ouça suas reivindicações. Os povos indígenas nunca foram invisíveis, mas sim vistos por um ângulo invertido.

A percepção da sociedade brasileira dos "homens brancos" concebia os povos indígenas como incapazes. E, sobre essa "incapacidade", de novo o autor afirma: "eram muito comuns os comentários sobre a incapacidade gerencial dos povos indígenas, o que gerou uma nova demanda: a capacitação das lideranças indígenas para administração dos recursos públicos" (MUNDURUKU, 2012, p. 57). 
O discurso da sociedade brasileira dos "homens brancos", ao expor os povos indígenas como incapazes e sem uma identidade étnica reconhecida, promovia ao mesmo tempo sua "ausência" nas discussões de interesse dos povos indígenas. É essa ausência de identidade e esse projeto que o autor ainda questiona. "E como essa identidade e esse projeto poderia estar a serviço de uma concepção de futuro dentro de uma sociedade que se caracteriza pela ausência de um pensamento que elabora o tempo futuro"? (MUNDURUKU, 2012, p. 62).

Para o autor, um projeto de futuro não pode ser exitoso para uma sociedade, e aqui se trata de uma sociedade indígena que foi até certo período caracterizada pela "ausência". Dadas as circunstâncias em que viveram e ainda vivem os povos indígenas, Daniel Munduruku é uma referência nacional.

Por se tratar de uma etnia que, apesar das algumas conquistas, ainda enfrenta enormes obstáculos no que se refere à efetivação dos seus direitos em geral, mas especificamente a demarcação de suas terras, Daniel Munduruku deve ser lido e ouvido no campo educacional. Tomo emprestada parte de sua fala no II Congresso Métodos Fronteiriços, realizado em 2017 pela Universidade Federal de Rondônia: "Os povos indígenas têm muito a ensinar, o que é preciso fazer é dispor de tempo para ouvi-los, mas não aquele ouvir rápido, e sim um ouvir com atenção e interesse". O que nos parece faltar é esse tempo de audição para ouvir o que outro tem a nos dizer.

Penso que a obra de Munduruku deve ser lida com muita atenção e reflexão, não apenas na Academia, mas nas escolas públicas, justamente por se tratar de um livro produzido para o contexto educacional brasileiro. Sua adoção pelas escolas da rede pública é fundamental para que seja desmistificado o discurso reducionista, desqualificador e rancoroso que ainda reside no nosso imaginário social, promovido por um grupo interessado em tomar e explorar as terras indígenas. 


\section{Referências bibliográficas}

CARNEIRO DA CUNHA, Manuela. Índios no Brasil: história, direitos e cidadania São Paulo: Claro Enigma, 2012. Disponível em https://www.companhiadasletras.com.br/trechos/35025.pdf,. Acesso em 11 maio 2018.

Índios no Brasil: História, Direitos e Cidadania. São Paulo: Companhia das Letras, 2013.2 Disponível em: https://www.companhiadasletras.com.br/trechos/35025.pdf. Acesso em: 03 set. 2017.

FARAGE, Nádia. As Muralhas dos Sertões: Os Povos Indígenas No Rio Branco e a Colonização. Editora ANPOCS, Paz e Terra, 1991. Disponível em: http://www.anpocs.com/index.php/universo/acervo/biblioteca/livros/255-as-muralhasdos-sertoes-os-povos-indigenas-no-rio-branco-e-a-colonizacao. Acesso em: 11 maio 2018.

MUNDURUKU, Daniel. O caráter educativo do movimento indígena brasileiro (1970- 1990). São Paulo: Paulinas, 2012. 